\title{
PERMASALAHAN MENGENAI SAMPAH ORGANIK DAN NON ORGANIK DI DESA TEGAL KERTHA
}

\author{
Lailatul Fitria dan Gine Das Prena \\ Jurusan Manajemen, Fakultas Ekonomi dan Bisnis, \\ Universitas Pendidikan Nasional Denpasar \\ E-mail : lailatulfitri0501@gmail.com
}

\begin{abstract}
ABSTRAK
Desa Tegal Kertha merupakan sebuah desa di tengah pusat Kota Denpasar yang dikenal memiliki aktivitas dan lalu lintas yang cukup padat baik dari kegiatan perekonomian, sosial budaya dan lain sebagainya. Segala keperluan yang kita butuhkan dapat dengan sangat mudah ditemukan disana. Tingginya aktivitas masyarakat menimbulkan suatu konsekuensi atas aktivitas tersebut. Dimana setiap aktivitas tentu menghasilkan residu atau limbah. Contoh kecilnya saja aktivitas bernafas yang menghasilkan limbah berupa gas karbondioksida. Begitu pula aktivitas kehidupan sehari-hari masyarakat Desa Tegal Kertha yang tinggi dan padat populasi tentunya akan menghasilkan limbah berupa sampah. Pengolahan limbah haruslah dilaksanakan dengan tepat dan cermat. Jika tidak maka akan timbul permasalahan baru. Seperti contohnya yang penulis temui di lapangan yaitu penumpukan sampah dan pemilahan sampah yang tidak efisien. Oleh karena itu dibutuhkan cara mengantisipasi penumpukan sampah tersebut dan mengelola jenis sampah dengan tujuan terciptanya pengelolaan sampah yang efisien, efektif dan sistematis. Salah satunya melalui penyusunan formatur petugas kebersihan yang baik dan terencana dan penyediaan wadah pemilahan sampah dari bahan yang mudah di dapat.
\end{abstract}

Kata kunci: sampah organik dan non organik, di desa tegal kertha

\section{PENDAHULUAN}

Kuliah Kerja Nyata (KKN)

Universitas Pendidikan Nasioanal

merupakan salah satu implikasi dari Tri

Dharma Perguruan Tinggi yaitu

pengabdian masyarakat. KKN bagi

mahasiswa diharapkan dapat menjadi

suatu pengalaman belajar yang baru

untuk menambah pengetahuan,

kemampuan, dan kesadaran hidup

bermasyarakat. Bagi masyarakat sasaran,

kehadiran mahasiswa diharapkan mampu

memberikan motivasi dan inovasi dalam

bidang pembangunan. KKN adalah suatu bentuk pendidikan dengan cara memberikan pengalaman belajar kepada mahasiswa untuk hidup ditengah-tengah masyarakat diluar kampus, dan secara langsung mengidentifikasi serta menangani masalah-masalah yang dihadapi.

Indonesia merupakan salah satu negara yang memiliki jumlah penduduk sangat besar di dunia setelah negara China dan India. Semakin bertambahnya jumlah penduduk dari waktu ke waktu menimbulkan banyak permasalahan yang terjadi. Salah satu akibat dari semakin 
bertambahnya jumlah penduduk tersebut adalah bertambahnya limbah atau buangan sampah yang dihasilkan penduduk setiap hari. Limbah sampah yang ditimbulkan terutama di daerah perkotaan telah menjadi permasalahan lingkungan yang harus ditanggulangi oleh stakeholders yakni pemerintah, pihak swasta dan juga masyarakat. Permasalahan ini dapat dilihat dihampir sebagian kota-kota besar di Indonesia.

Sampah pada dasarnya dihasilkan oleh atau merupakan konsekuensi dari adanya aktifitas manusia. Hukum termodinamika kedua menyatakan bahwa hakikatnya proses perubahan materi atau proses produksi apapun tidak ada yang berjalan efisien 100 persen. Setiap aktifitas manusia pasti menghasilkan buangan atau sampah yang jumlah dan volumenya sebanding dengan tingkat konsumsi kita terhadap barang atau material yang kita gunakan sehari - hari. Demikian juga dengan jenis sampah, sangat tergantung dari gaya hidup dan jenis material yang dikonsumsi masyarakat. Penanganan dan pengelolaan sampah sampai saat ini masih belum optimal. Sebagian besar penduduk masih melakukan proses penanganan dan pengelolaan sampah dengan sistem konvensional yakni
Kumpul-Angkut-Buang dengan penyelesaian akhir di TPA (Tempat Pembuangan Akhir). Permasalahan lain yang berpengaruh terhadap penanganan dan pengelolaan sampah adalah tingginya biaya operasional dan semakin sulitnya ruang yang sesuai untuk pembuangannya.

Termasuk yang terjadi di Desa Tegal Kertha, Kecamatan Denpasar Barat, Kota Denpasar. Sampah menjadi masalah sosial sekaligus masalah lingkungan di daerah tersebut yang tentunya memiliki dampak negatif. Apabila tidak segera dilakukan penanganan untuk mengatasi masalah tersebut dikhawatirkan dampak negatif tersebut dapat semakin besar bahkan meluas. Pemerintah yang berwenang di daerah setempat sudah menyediakan Tempat Pembuangan Akhir dan petugas yang memiliki tugas menjemput sampah secara rutin dan berkeliling dari rumah ke rumah. Akan tetapi muncul masalah baru lagi baik dari petugasnya yang datang tidak sesuai jadwal sehingga sampah menumpuk maupun dari masyarakatnya sendiri seperti contohnya tidak mengindahkan himbauan agar memisahkan sampah organik dan non organik. 


\section{METODE}

Dalam pelaksanaan program Kuliah Kerja Nyata (KKN) dan demi kelancaran program kerja yang telah saya susun dengan sedemikian rupa untuk di implementasikan pada masyarakat di daerah sasaran yaitu Desa Tegal Kertha, maka langkahlangkah yang saya tempuh yaitu dengan memberikan penjelasan kepada para petugas sampah untuk bersedia dengan adanya cadangan dalam pengambilan sampah apabila petugas yang seharusnya bertugas sedang sakit atau sedang berhalangan. Selanjutnya mengenai kerjasama dalam memanfaatkan sampah non organik agar dapat didaur ulang dan dijadikan tempat sampah untuk didistribusikan kepada masyarakat demi terciptanya pengelolaan sampah yang efektif melalui pemilahan jenis sampah organik dan non organik. Selama ini masyarakat mengalami kendala khususnya dalam hal penempatan sampah, dengan adanya tempat sampah daur ulang tersebut diharapkan dapat menjadi solusi karena tidak tersedianya tempat sampah dari petugas kebersihan.

\section{HASIL DAN PEMBAHASAN}

Desa Tegal Kertha memiliki populasi penduduk yang cukup tinggi karena berada di daerah perkotaan yang merupakan pusat ekonomi. Aktivitas penduduk yang padat tentu berdampak pula pada limbah yang dihasilkan baik dari kegiatan rumah tangga seperti memasak, kegiatan perekonomian seperti limbah kemasan, kegiatan perkantoran seperti limbah kertas maupun limbah dari aktivitas alam seperti daun kering, ranting, dan lain sebagainya. Hal tersebut jika tidak diatasi tentunya akan menimbulkan masalah yang baru lagi baik terhadap lingkungan maupun sosial budaya. Pemerintah Desa Tegal Kertha telah berupaya untuk memecahkan masalah tersebut melalui program penjemputan sampah secara berkeliling dan juga pemilahan jenis sampah di tingkat paling rendah yaitu rumah tangga. Akan tetapi, timbul permasalahan baru yaitu keterlambatan penjemputan dan tidak adanya wadah untuk memilah sampah.

Dalam kegiatan KKN ini, saya berusaha menghadirkan inovasi sekaligus solusi bagi permasalahan tersebut melalui adanya petugas cadangan mengenai pengambilan 
sampah dan pembuatan produk tempat sampah dari bahan daur ulang untuk didistribusikan kepada masyarakat. Hasil dari program kerja tersebut antara lain :

1. Jadwal pengambilan sampah yang sebelumnya sering terlambat menjadi lebih teratur karena adanya petugas kebersihan cadangan yang siap menggantikan petugas utama ketika berhalangan. Sehingga penumpukan sampah dapat diminimalisir resikonya. Siklus sampah yang berlangsung tanpa hambatan atau penumpukan akan mempermudah proses pengolahannya di TPA dan jalur selanjutnya.

2. Masyarakat yang sebelumnya malas untuk memisahkan sampah berdasarkan jenisnya ternyata disebabkan oleh tidak tersedianya wadah sampah dari petugas. Dengan adanya wadah sampah daur ulang, masyarakat lebih tergerak untuk memisahkan sampah ke dalam jenisnya masingmasing karena sudah di fasilitasi wadah untuk memisahkan sampah tanpa harus membeli kresek atau trashbag secara mandiri dan berulang kali.
3. Masyarakat melakukan upaya swadaya untuk menabung di bank sampah. Karena sampah yang telah terpilah di tingkat rumah tangga individu memudahkan petugas bank sampah dengan tidak lagi memilah-milah sampah pada bank sampah. Serta sampah pun bisa menghasilkan ketika ditabung di bank sampah.

\section{Rencana produk kreatifitas}

Berdasarkan hasil produk kreatifita tersebut pengabdi memiliki rancangan produk tempat sampah yang terbuat dari bahan daur ulang. Produk tersebut yaitu "tempat sampah". Adapun rancangan awal produk tersebut dan dokumentasi kegiatan yaitu :

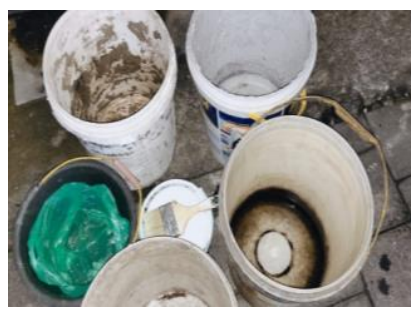

Gambar 1. Ember Bekas, Cat, dan Kuas

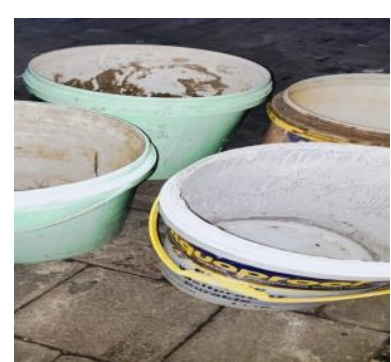

Gambar 2. Proses pengecatan 


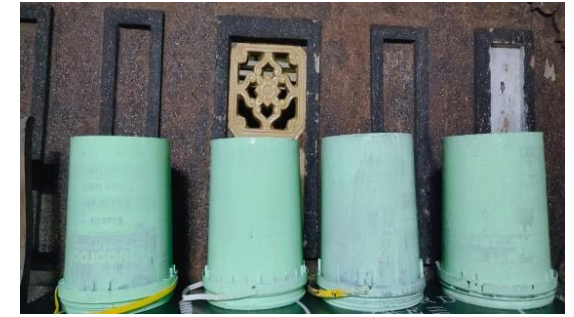

Gambar 3. Hasil dari tempat sampah daur ulang

\section{KESIMPULAN}

Melalui kegiatan pengabdian ini peneliti memiliki ide untuk membuat produk daur ulang dari hasil ember bekas dapat membuat masyarakat sekitar memiliki tempat sampah organik dan non organik yang seblumnya hanya memiliki satu tempat sampah saja.

\section{DAFTAR PUSTAKA}

file:///C:/Users/Fitri/AppData/Local/Te mp/LAPORAN\%20KKN\%20230 3\%20UNY\%20.pdf

file:///C:/Users/Fitri/AppData/Local/Te mp/LapAkhir_KKNPPM_Sugen gEkoPW_UMPurworejo.pdf

(Armadi 2021)Armadi, Ni Made. 2021. "Peran Serta Masyarakat Dalam Pengelolaan Sampah Sebagai Kunci Keberhasilan Dalam
Mengelola Sampah.” Jurnal

Ilmu Sosial dan Ilmu Politik: 924.

(Mardiana et al. 2019)Mardiana, Siska, Rethorika Berthanilla, Marthalena Marthalena, and Muhammad Ryan Rasyid. 2019. "Peningkatan Pengetahuan Masyarakat Mengenai Pengelolaan Pembuangan Dan Pemilahan Sampah Rumah Tangga Di Kelurahan Kaligandu Kota Serang." Bantenese Jurnal Pengabdian Masyarakat 1(2): 79-88.

(Taufiq and Maulana 2015)Taufiq, A, and F. M. Maulana. 2015. "Sosialisasi Sampah Organik Dan Non Organik Serta Pelatihan Kreasi Sampah." Jurnal Inovasi dan Kewirausahaan 4(1): 68-73.

(Wahyuning, Sunarto, and Wiryanto 2015)Wahyuning, Sri, Sunarto, and Wiryanto. 2015.

"Pengelolaan Sampah Berbasis Peran Serta Masyarakat Di Desa Kalibeber ,." Prosiding SNPBS (Seminar Nasional Pendidikan Biologi dan Saintek) Ke-2 IsuIsu Strategis Sains, Lingkungan, dan Inovasi Pembelajarannya. 